\title{
ハンドボール選手における 肩関節機能と損傷との関係について
}

\author{
花岡美智子宮 永豊白木 仁
}

向井直 樹 宮川俊平

\section{THE RELATIONSHIPS BETWEEN SHOULDER'S FUNCTION AND DAMAGE FOR HANDBALL PLAYERS}

\author{
Michiko HanaOKa, YUtaka Miyanaga, Hitoshi SHiraki, \\ NAOKI MUKaI and SHUNPEI MiYAKAWA
}

\begin{abstract}
【Objective】 The purpose of this study is to examine the relationships between shoulder's function and damage for handball players. Subjects were nine female handball players with dominant shoulder pain.

【Methods】 Clinical diagnosis was done from the medical doctor's opinion and MRI. Then, the shoulder joint movement was measured with $\mathrm{X}$ rays.

【Results】 Most of them had admitted a lot the impingement syndrome and the subacromial bursitis. The trunk rotation angle at zero-positions was significantly larger in the symptomatic shoulder (dominant shoulder) than in the asymptomatic shoulder (nondominant shoulder). That is, it was obvious that the damage of the shoulder changed tilting angle of scapula medially.

【Conclusion】 It is reported that the damage of the shoulder causes abnormality to the "scapulohumeral rhythm" by the previous research. But, these results, suggested to need to understand not only "scapulohumeral rhythm" but also movement to the position of the scapula, when the shoulder joint function was observed for the handball player mainly composed of throwing motion.
\end{abstract}

(Jpn. J. Phys. Fitness Sports Med. 2005, $54: 179 \sim 184$ )

key word : shoulder's function, scapulohumeral rhythm, damage, handball players

\section{I . 緒言}

ハンドボールはルール上コンタクトが許されてい るスポーツであり，兴の種目特性上，多角度から狙 うシュート，ディフェンスをかわして打つシュート など，変則的なフォームでの投動作が多く見られ る.さらに投動作中にコンタクトを受けることもあ り，肩の前方に大きなストレスが加わる場合も多 く, 肩関節損傷の発生しやすい競技の一つであると 言える .

肩関節は解剖学的な関節と機能的な関節により構 成される肩関節複合体 (Shoulder complex)として機 能している，肩関節複合体は，各々の関節および機 構の間で非常に優れた代償機能を有している反面， ある部位(関節)で既に許容能力を越えても，他での
代償機能が働くため，関節の異常や痛みを感じるの が遅いという現象を引き起こしている. 兴の結果肩 の損傷は，症状が発生した時には既に重症である ケースが多く，慢性化しやすいため，非常に深刻な 損傷部位の一つであると考えられている .

肩関節の疾患を診断する方法の一つとして，肩関 節機能の評価を行う肩甲上腕リズムが挙げられる． 肩甲上腕リズムは上腕骨挙上に付随して回旋する肩

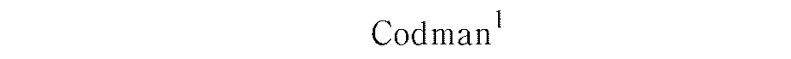
Inman ら ${ }^{2)}$ はこのリズムを研究し, 挙上運動時に上 腕骨と肩甲骨が $2: 1$ の割合で動くことを発表した . さらに肩甲上腕リズムは impingement 症候群や腱 板損傷など，樣々な疾患により容易にリズムの異常 をきたすと言われている ${ }^{3 \sim 6)}$. ハンドボールに限 らずスポーツによる肩の損傷は，投動作が発生機序 
となるものがほとんどである . 投動作は肩関節複合 体の中でも主に肩甲胸郭関節と肩甲上腕関節によっ て行われているため，肩関節損傷の診断として肩甲 上腕リズムを観察することは必要であると考えられ る.

また Saha ${ }^{7)}$ によって「上腕骨軸と肩甲棘が一線 の軸にあり，肩関節の筋群は円錐状にこの軸と一致 する上肢挙上肢位」と定義されたゼロポジションは， 関節面の接地面積が最大 腱板の張力が一定となり， 最も安定しバランスがとれた状態にあると言われて いる．炎のため，投動作においてゼロポジションで ボールをリリースするフォームは構造的にも機能的 にも安定しており，投球障害を予防する効率的なフ オームと考えられている．

しかし, 先行研究は, 重度の症状を訴える一般患 者を対象としたものがほとんどで, 過剩な負荷を強 いられている投動作主体の競技選手を対象にした研 究は少ない.光こで本研究では, 肩関節に既往を有 するハンドボール選手を対象に，下垂位とゼロポジ ションにおける肩甲上腕関節と肩甲胸郭関節の角度 を測定し，肩の既往や競技との関連について検討を 行った .さらに , ハンドボール選手にみられる肩関 節の損傷状況を理学所見と MRI 所見から判断し， 肩関節機能との関係について検討することにより， スポーツにおける肩関節損傷に対する治療や予防の 一知見を見出すことを本研究の目的とした .

\section{II. 方法}

\section{A. 研究対象}

筑波大学女子ハンドボール部に所属する選手 9 名 を対象とした。被験者は全員，利き肩に既往歴，疼 痛症状を有しており，非利き肩には既往歴がなく症 状を有していない．被験者の平均年齢は $21.0 \pm 0.98$ 歳, 平均身長 $165.0 \pm 4.43 \mathrm{~cm}$, 平均体重 $59.3 \pm 4.64$ $\mathrm{kg}$ ，平均競技年数は $8.6 \pm 1.95$ 年， 7 名が右利き， 2 名が左利きであった．なお，全ての被験者に実験 内容や手順を説明し，十分に理解させた上で, 文書 による実験参加の同意を得た．なお本研究は筑波大 学体育科学系倫理委員会の承認を得て実施した。

\section{B. 測定項目}

\section{1 . 理学所見}

圧痛点(烏口突起，腱板間隙疎部，関節腔，結節
間溝，大結節，四角腔，棘下筋，肩甲骨上角)，他 動運動痛 (Neer test, Speed test, Yergason's test, 棘 上筋抵抗テスト, 棘下筋抵抗テスト, painful arc sign), 不安定感 (apprehension test, anterior drawer test, posterior drawer test, sulcus sign)の有無につ いて, 診断, 評価を行った .

2 . MRI 所見

永久磁石型MRイメージング装置 AIRIS-Mate(日 立メディコ社製)を用いて撮像を行った，撮像肢位 は仰臥位にて，手掌を前額面において上方を向いた 状態で，肩関節下垂位，90外転位，ゼロポジショ ンの3肢位を撮像した。撮像条件は, Fast Spin Echo(FSE)法による T2 強調画像 (TR/TE/FA： $3000 \mathrm{~ms} / 120 \mathrm{~ms} / 90 \mathrm{deg})$ で, スライスは12枚, スラ イス厚 $4.0 \mathrm{~mm}$ ，スライス間隔 $5.0 \mathrm{~mm}$ であった . マトリックスは $224 \times 192$, Field Of View(FOV : 撮 像領域)は $220 \mathrm{~mm}$ であった . 被験者の同意を得た 1 回の撮像映像時間は 5 分 24 秒であつた . 撮像面と して, 上腕骨骨頭と肩甲骨関節窩のなす関節面に垂 直な斜位冠状断像と, 上腕骨骨頭と肩甲骨関節窝の なす関節面に平行な斜位矢状断像を得た . 得られた 撮像は医師により診断された .

\section{3 . 肩関節運動}

遠隔操作形 X-TV 式 X 線透視撮影装置 DCW$10 \mathrm{~A}$ 型(TOSHIBA 社製)を用いて X 線を撮影し， Arm angle(A), Glenohumeral angle(G), Scapu-

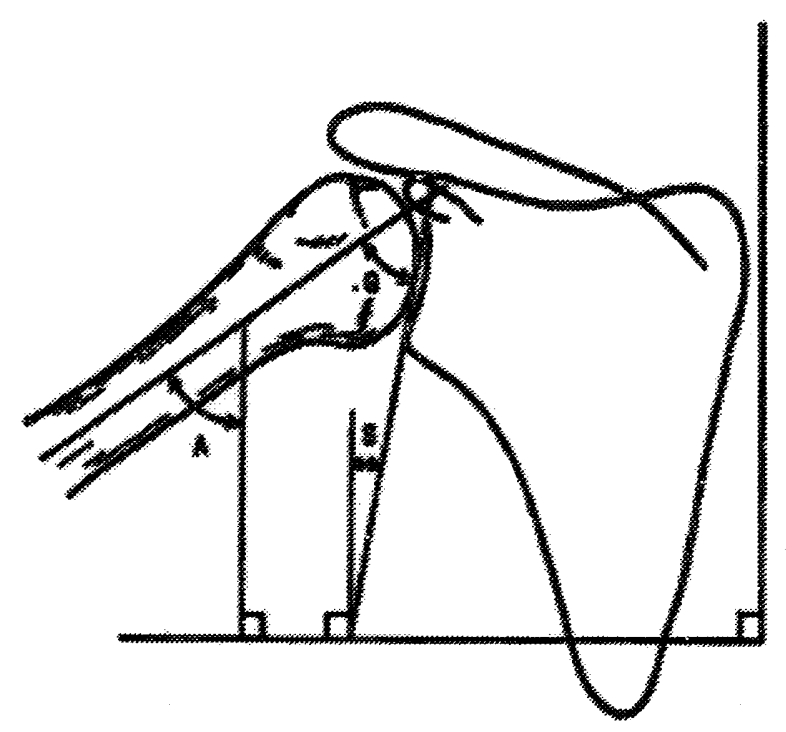

Fig. 1. Motion of the shoulder.

A) Arm angle G) Glenohumeral angle

S) Scapulothoracic angle 


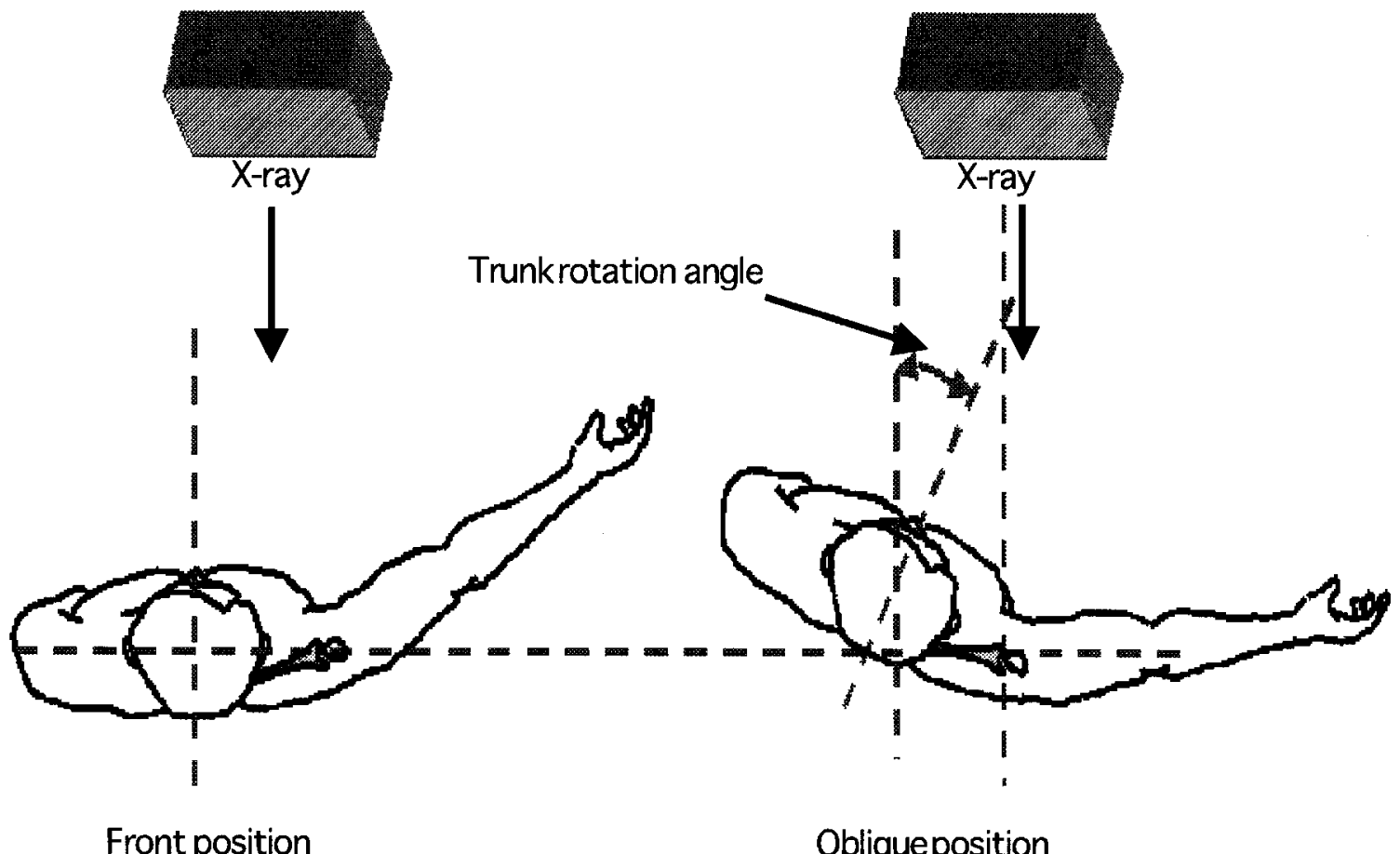

Fig. 2. Trunk rotation angle.

lothoracic angle(S), ゼロポジションにおけ る関節角度比, 上腕骨運動角度, 肩甲骨運動 角度, 上腕骨・肩甲骨の運動比, 体幹回転角 度を測定した(Fig. 1，Fig. 2)．立位において 下垂位と，肩甲骨面にて肩峰と上腕骨軸の一 致する位置(ゼロポジション)の 2 肢位を撮影 した．手掌は前方を向くように指示し，正面 像と臼蓋面が線状に写る斜位像を撮影した 。

なお，体幹回転角度は立位において，斜位 像を撮影する際に，正面から撮影肢位まで移 動した体幹の回転角度を測定した。

\section{III. 結果}

A. 理学所見, MRI 所見

既往を有するハンドボール選手の有症状肩(利き 肩)では理学所見において Neer test の陽性( 6 名), MRI 所見において肩峰下滑液包炎 ( 7 名)の所見が 多く認められた .

\section{B．肩関節運動}

体幹回転角度の項目で, ゼロポジションにおいて 有症状肩が無症状肩に対し，有意に高い值を示した (Fig. 3) . 兴の他の項目においては, 下垂位 , ゼロ ポジションともに有症状肩と無症状肩の間に有意な $\left({ }^{\circ}\right)$

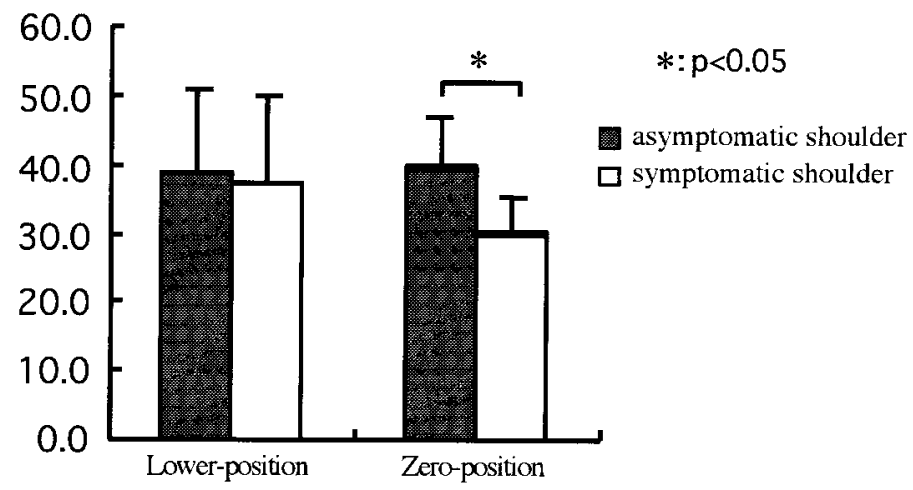

Fig. 3. Comparison of the average of trunk rotation angle between symptomatic shoulder and asymptomatic shoulder.

差は認められなかった .

$$
\text { N. 考察 }
$$

A ．ハンドボール選手に見られる肩関節の損傷状 況

既往を有するハンドボール選手の有症状肩(利き 肩)では，理学所見において Neer test の陽性，MRI 所見において肩峰下滑液の所見が多く認められた .

肩峰下に発生する impingement は, 肩峰と烏口 肩峰靭帯からなる肩峰下面と, 肩峰下滑液包・腱板 との間で生じる機械的ストレスによって発生する . 
この機械的ストレスはフォームの不良，肩甲胸郭関 節の機能障害 , 腱板の機能低下が原因で引き起こさ れると言われている8) . ハンドボールでは, 競技中 に投動作が頻繁に行われることに加えて，サイドか らのシュートやディフェンスの間を狙ったサイドス ローでのシュートなど，無理な体勢から投動作を行 う機会が多い . over use やフォームの不良が，腱に 異常な力を加え, 肩峰下に impingement を引き起 こしていると考えられる .

\section{B . 肩関節損傷の既往，投動作主体の競技が肩関} 節運動に及ぼす影響

肩関節運動として，有症状肩と無症状肩の間で有 意な差が認められたのは，ゼロポジションにおける 体幹回転角度のみであった．本研究では，体幹回転 角度を肩甲骨の前額面に対する傾き，肩甲骨の内方 傾斜角度と考えた。

肩甲骨の内方傾斜角度については，いくつかの先 行研究が行われてきたが, これまで一致した見解が 得られていない.しかし，いずれの先行研究 ${ }^{3,9)}$ に おいても左右差が認められたと報告されているもの はない.

本研究では, ゼロポジションにおける体幹回転角 度は，有症状肩である利き肩 $\left(39.7 \pm 6.95^{\circ}\right)$ が無症 状肩である非利き肩 $\left(30.1 \pm 4.99^{\circ}\right)$ に対して有意に 高い值を示し, 先行研究とは異なる結果を得た。こ れは対象が先行研究では健常者であるのに対し，本 研究では利き肩に既往を有するハンドボール選手で あったことによると思われる．

肩甲骨の内方傾斜角の増加は，肩甲骨の胸郭上に おける外転運動が増加することに付随して見られる 現象である . 肩甲骨の胸郭上の外転運動は，肩関節 が内旋，水平屈曲運動を行う場合に行われる. 光 のため, 肩甲骨の内方傾斜角を増加させる因子とし て，肩甲骨の外転を導く作用を持つ前鋸筋，肩関節 の内旋, 水平屈曲を行う大胸筋の関与が考えられ る .これらの筋は，肩甲骨を胸郭に押しつけ安定さ せる作用も持っている . 投動作において肩関節は， late cocking 期に最大外転外旋を行い, 弚の後 acceleration 期において肩の急激な内旋内転を行う. 投球動作時の筋活動を記録した先行研究 ${ }^{10)}$ による と, acceleration 期において大胸筋や前鋸筋の活動 が活発になることが明らかにされており，これらの
筋は腕やボールの加速に直接関与していると考えら れている。

ハンドボールのように投動作が頻繁に繰り返され る競技選手にとって，ボールに速度を加え，よりパ フォーマンスを向上させる目的で，また競技におけ る頻回の投動作に耐えるために肩甲骨の安定化を図 り，障害を予防する目的で前鋸筋や大胸筋の筋力強 化を行うことは専門種目の適応の一つとして重要で あると考えられ，光れは健常者よりも既往を有する 選手に顕著であると思われる .これが肩甲骨の胸郭 上での外転運動を助長し，挙上位において肩甲骨の 内方傾斜角の増加が見られた一因であると思われ る.

C. ハンドボール選手における肩関節機能と損傷 との関係について

ハンドボール選手の利き肩では, 理学所見におい て Neer test の陽性, MRI 所見において肩峰下滑液 包炎の所見が多く認められた . Neer test の陽性の 場合，主に腱板，肩峰下滑液包に起因する疾患が疑 われる.これらの肩損傷の発生機序としては, over use が考えられる . ハンドボールにおいては，多角 度から狙うシュート，ディフェンスをかわして打つ シュート, 密集地帯からクイックで打ち込むシュー 卜など，樣々なフォームでの投動作も多く見られ る. Romain ら"1)はドイツの地域・地元リーグに属 する男子ハンドボールチームの選手を対象に1シー ズンを通しての傷害調査を行い, 肩関節の障害が最 も多いことを報告した . 佐久間ら ${ }^{12)}$ は , ハンドボー ル全日本女子選手を対象にメディカルチェックを行 い, 投球障害肩による肩関節痛(腱板損傷を含む)お よび動摇肩を含めた肩関節障害が最も多い障害であ ると報告している．また Gohlke ら ${ }^{13)}$ は overhead stress が加わる high performance athlete の, 肩関 節の動摇や impingement の発生割合は , バスケッ トボール $3.5 \%$ ， バレーボール $25 \%$ に対し，ハンド ボールでは $40 \%$ にのぼると報告している．またコン タクトプレーが許されている競技特性から，投球方 向とは逆方向への強いストレスが肩に加えられ、肩 の前方に大きなストレスが加わる場合も多くみられ る.

以上より，ハンドボール選手は over use による 慢性的な肩障害に加え、シュート時に加えられる突 
発的な外力による微小外傷により慢性的な肩損傷に 発展していることが多いように思われる．

そ汭う肩損傷の既往を利き肩に有するハンド ボール選手に見られた肩関節機能の異常は, 肩甲上 腕リズムを構成する肩甲上腕関節, 肩甲胸郭関節角 度ではなく，肩甲骨の内方傾斜角度であった .この 違いは研究における対象のバックグランドの違いに 伴うものと考えられる. 先行研究では対象は一般人 であるのに対し，本研究では投動作を主体とするハ ンドボール選手か㳔象であった .さらに先行研究で は可動域制限を生じる腱板断裂や肩関節周囲炎が症 例であるのに対し, 本研究では可動域制限がなく， 競技を行うことも可能である比較的軽症な impingement 症候群, 動摇性肩を症状として有しているも のが多かった . 可動域制限が見られるほどの損傷を 有している場合，腱板筋群の骨頭を関節墖へ安定化 させる作用が損傷により低下しているために, 肩甲 骨の上方回旋角度力増加する傾向にある. 弚れによ り，肩甲上腕リズムに破綻を生じる，一方，競技を 行うことが可能であり，可動域制限も見られないよ うな軽度の損傷の場合には，腱板断裂や筋の拘縮は ほとんどなく，腱板により骨頭を関節窩へ安定化さ せる作用か機能しているため，肩甲上腕リズムの乱 れが見られなかったと思われる .

肩関節機能と言えば，肩甲上腕リズムに代表され る上肢挙上運動における機能を指すことが多く，肩 甲骨の運動においては上方回旋運動に着目すること が多かった．しかし，実際の競技場面において外転 運動のみが行われることはほとんどありえない，投 動作中, 肩関節は外転, 外旋運動を行い关の後内転， 内旋運動を行う．光の際肩甲骨も上方回旋のみでは なく, 上肢の動きに伴って内転・外転, 上方回旋 · 下方回旋，挙上・降下など多方向へ運動を行ってい る. 兴のため，投動作主体の競技を行う選手に対し て肩関節機能を見る場合には，肩甲骨の上方回旋の みではなく多方向への動きについても着目する必要 があると思われる．

可動域制限を生じないような軽度な症状では，肩 関節複合体の機能として代償作用が働き，パフォー マンスを著しく低下させることがないため，十分な トレーニングや治療を行わず放置されることが多 い、しかし放置することにより競技から長期離脱を 余儀なくされてしまうような重篤な障害へ発展する
恐れがあり，弚のような状態を避けるためにも，比 較的軽症である段階においてトレーニングや治療を 行うことが重要かつ必要となってくる. 本研究より 投動作主体の競技選手において比較的早期に肩の損 傷を発見するためには，肩甲上腕リズムとともに肩 甲骨の位置や多方向への動きを把握する必要がある ことが示唆された .

\section{V. 結 論}

A． 既往を有するハンドボール選手において，impingement 症候群，肩峰下滑液包炎が多く認め られた。

B. ゼロポジションにおいて，体幹回転角度は有症 状肩(利き肩)が無症状肩(非利き肩)に対して有 意に高い値を示した，すなわち，有症状肩は， 無症状肩に比へて肩甲骨の内方傾斜角か増加す る傾向を示した。

C. 投動作を主体とするハンドボール選手に対し て, 肩関節機能を見る場合には, 肩甲上腕リズ ムとともに肩甲骨の位置や多方向への動きを把 握する必要があることが示唆された .

(受理日 平成17年 2 月 21 日)

\section{引用・参考文献}

1) Codman E. A. : The Shoulder. T. Todd Co. : Boston, 1934

2) Inman V. T., Saunders J. B., Abbott L. G. : Observations on the function of the shoulder joint. J. Bone and Joint Surg. $26: 1-30,1944$

3) 伊藤信之ら：腱板断裂例の肩甲上腕リズムの分析 . 整形外科と災害外科. 45(4)：1131 - 1134, 1996

4) 衛藤正雄 : 肩関節周囲炎における scapulo-humeral rhythm の分析 . 日整会誌 . 65：693-707，1991

5) 尾崎二郎：Cineradiography と挙上位X線像からみた 肩関節の動態学的研究. 日整会誌. 54：1679-1692, 1980

6) 河本定尚：肩腱板断裂症例の筋電図学的検索 . 日整 会誌. 60：1239-1249,

7) Saha A. K. : Theory of Shoulder Mechanism. C. C Thomas : Springfield, 1961

8) 山口光國, 筒井廣明 : 投球肩の発生理論とリハビリ テーションー特に肩甲上腕関節機能について. Sportsmedicine Quarterly. 12:95-102，1993

9) 田副司郎：肩甲骨の傾きに関する研究 . 日整会誌. $57: 767-778,1983$

10) Gowan I. D., F.W.Jobe, J. E. Tibone, J.Perry, D. R. Moynes: A comparative electromyographic analysis of the shoulder during ppitching. -Professional versus 
amateur pitchers.- Am. J. Sports Med. 15 : 586-590, 1987

11) Romain S., Siegbert T. : Sports Injuries in Team Handball. 肩関節 . 24 (2) : 159-162, 2000

12) 佐久間克彦ら：ハンドボール全日本女子の外傷 · 障害について . 九州・山口スポーツ医・科学会誌.
$12: 46-49,2000$

13) Gohlke F. : Instability and impingement of the shoulder of the high performance athlete in overhead stress. Sportverletzung Sportschaden. $7: 115^{-121,}$ 1993 